\title{
Türkiye'de Ulusal Birlik Algısını Ölçmek: Sakarya Örneği
}

A Study on the Validity and Reliability of National Unity/Identity Perception Scale

\section{Mustafa Kemal Şan}

Handan Akyiğit

\section{$\ddot{O} z$}

Bu çalışma Türkiye'de yaşayan bireylerin toplumsal birlik ve beraberliğe yönelik bakış açılarının ortaya çıkarılabilmesi için "Ulusal Birlik Algısı Ölçeğì"nin geliştirilmesi amacıyla yapılmıştır. Bu amaçla literatür bilgilerinden de faydalanarak araştırmacı ve bu alanda uzman 3 kişi ile madde havuzuna bireylerin ulusal birliğe yönelik bakış açılarını ortaya çıkarıcı 43 durum yazılmıştır. Daha sonra ölçek geliştirme konusunda çalışmış 3 uzman akademisyenle madde havuzunda ifadeler üzerinde birlikte çalışılmıştır. Onlardan gelen dönütler doğrultusunda gerekli düzeltme işlemleri yapılarak 43 maddelik ulusal birlik ölçeği ön deneme uygulamasına hazır hale getirilmiştir. 43 maddelik deneme formu, Sakarya ili sınırları içerisinde yaşamakta farklı kültürel yapılara ve etnik kökene sahip 293 katılımcıya uygulanmıştır. Açımlayıcı faktör analizleriyle (AFA) toplamda 35 maddeden oluşan bir yapıya ulaşı1mıştır. Analizlerde ölçeğin alt ölçekleri arasındaki ilişkiye bakılmış ve faktörlerin birbirleriyle olumlu ve anlamlı ilişki içinde olduğu görülmüştür. Alt boyutların ulusal birliği sağlayan temel unsurlar olarak adlandırılan bir yapının bileşenleri olduğu ve bunların birlikte bir üst yapıyı oluşturduğu yapılan analizler sonucunda doğrulanmıştır. Modelin uyum indekslerinin oldukça yüksek olduğu belirlenmiştir. Doğrulayıcı faktör analizi de AFA sonuçlarını doğrulamıştır. Ölçeğin tümü için iç tutarlılık katsayısı ise .86 olarak belirlenmiştir.

Anahtar Kelimeler: Ulus Devlet, Ulusal Kimlik, Ulusal Birlik, Millet.

Prof. Dr., Sakarya Üniversitesi, Fen Edebiyat Fakültesi, Sosyoloji Bölümü, mksan@ sakarya.edu.tr

Arş. Gör., Sakarya Üniversitesi, Fen Edebiyat Fakültesi, Sosyoloji Bölümü, hakyigit@ sakarya.edu.tr

Bu makale iThenticate sistemi tarafından taranmıştır.

Makale Gönderim Tarihi: 22.01.2016

DOİ: 10.17550/aid.61971 


\begin{abstract}
This work aims to develop and improve a "Scale of National Unity Perception" that help us to analyze the Turkish citizens' perspectives on social unity and solidarity. For this aim, using the literature and experience of three experts in this area, we formed a pool of items consisting of 43 situation-cases in order to detect the perspectives of individuals on the national unity. Later, we worked together with these three expert academics to develop the pool. We made the necessary adjustments in accordance with their feedback, we formed a 43-point scale of national unity for the pre-trial application. The 43-items test form was then applied to 293 participants with different cultural and ethnic backgrounds from the city of Sakarya. With the Exploratory Factor Analysis (EFA) and a structure consisting of a total of 35 items. We checked the relationship between the scale with its subscales, we concluded that they are positively and significantly correlated with each other. It has looked at the relationship between the subscales of the scale of the factors in the analysis and was found to be positively and significantly correlated with each other. Through the analyses conducted, we confirmed that the subdimensions of the scale are components of its basic elements and they form together a structure of national unity scale. The conformity index of the model is quite high. Confirmatory factor analysis has also confirmed the results of the EFA. The internal consistency coefficient for the whole scale was determined to be .86 .
\end{abstract}

Keywords: Nation, Nation State, National Identity, National Unity. 


\section{Giriş}

İki kutuplu sistemin yıkılmasından sonra oluşan uluslararası politik düzen birçok kavramı, kuramı ve olguyu tartışılır duruma getirmiştir. Değişen koşulların ortamında tarihin eski dönemlerinden gelen kavramlar yeni nitelik ve sonuçlarla tekrar gündeme gelmişlerdir. Bu durum günümüz olgularının yeniden yorumlanmasını, anlamlandırılmasını ve kategorileştirilmesini gerektirmiştir. Küreselleşme, post-modernizm ve bu süreçlerin sonucunda siyasal alanda beliren çokkültültürcü politikalar kapsamında okunmaya başlayan ulus devlet'in toplumsal, kültürel yapısının yeniden sorgulanmasına neden olmuştur. Bunun sonucunda akademik yazın alanında etnik, etnik grup, ulusal azınlık, etnik devlet, kültürel hak ve talepler, özerklik gibi kavramlar sıkça tartışılan kavramlar olarak yerini almışlardır. Genel nitelikleri bakımından farklı etnik kimliklerin tanınması ve hakları, etnik hareketler, etnik asimilasyon, gerilim, çatışma ve ayrımcılık sorunları çerçevesinde benzerlikler arz eden ulus devlet yapılanmasına dair çeşitli konular devletlerin yeniden sosyo-kültürel, politik yapılanmasını sorgulamasıyla sonuçlanmıştır. Türkiye'de ise bu sorgulama ve politik arayış genelde iki duruş temelinde ilerlemektedir. Bunlar her türlü kimliğin, azınlık grubunun sorgulanmadan "öteki”"leştirilerek yok sayıldığı duruş ile kendini bir değer olarak sorgulamadan "kutsayan" duruştur. Bu çalışma ise bu iki temel duruş dışına çıkabilmek için ulus devletin varlığının temel dayanak noktasının neler olduğunu sorgulayabilmek amacıyla ele alınmıştır. Bu nedenle çalışmanın ilk bölümünde ulus, devlet, millet kavramlarının temel dayanak noktalarına odaklanacaktır. İkinci bölümde ise teorik kuramsal tartışmalar bağlamında Türkiye'de ulusal birliği sağlayan temel değerlerin hangi konular kapsamında ele alınabileceğini tartış1lacaktır. Son bölümde ise ulusal birliğin temel dayanak noktalarının açığa çıkartmak maksadıyla geliştirilmiş olunan "Ulusal Birlik Algısı" ölçeğinin güvenilirlik ve geçerlilik analizlerine dair bilgi verilerek ölçeğin kapsam ve içeriğinden bahsedilecektir.

\section{Ulus Devlet, Ulusal Kimlik ve Millet}

Durkheim, "devlet her şeyin üzerinde bir düşünce aracıdır. O belirsiz güdülerin yerini alan zekadır" (akt. Guibernau, 1996: 26) derken kuşkusuz tüm düşüncelerin devletten kaynaklandığını, sivil insanların 
düşünce kabiliyetlerinin olmadığını kastetmemektedir. Kültürel kalıpların sorgulanmadan kabul edildiğini ve her defasında bunlar üzerinde düşünülerek hareket edilmediğini belirten Durkheim, tam tersine devlet yönetiminde sorgulanmadan kabul edilen, üzerinde her defasında uzlaşma sağlanan konuların hemen hemen olmadığını belirtmektedir (Giddens, 2005: 29-37).

Guibernau (1996: 44) ise ulus devleti "türdeşleştirme, ortak bir kültür, simgeler ve değerler yaratarak gelenekleri ve yaratılış mitlerini canlandırarak kimi zaman uydurarak halkı kendi yönetimi altında birleştirmeye çalışan bir olgu" olarak tanımlamaktadır. Navari (1981: 13) ulus devleti "aynı kültür ve dili paylaşan, kendilerinden birileri tarafından yönetilen ve onların menfaatine hizmet eden türdeş bir topluma hükmetme biçimi” olarak tanımlamaktadır. Bu iki tanım devletin, ulusun tüm kültürel özelliklerini ihtiva ettiğini ve söz konusu kültürel özelliklerin olmadığı ya da eksik olduğu yerlerde bunların devlet tarafından muhakkak icat edilmesi gerektiğini varsaymaktadır. Zira devlet kendi kaderini ulustan bağımsız bir biçimde belirleyemez. Bu nedenle ülke içinde "ulusal bir kimlik etrafında örgütlenmiş türdeş bir nüfus oluşturmak" önemli bir hal almaktadır.

Ulus devletin genel manada açıklamalarını incelendiğinde temel vurgunun sınırların kesin biçimde tanımlanışı, şiddet araçlarının kontrol tekelinin devlette olması, gücün gayri şahsiliği ve meşruiyet kavramları üzerinde olduğu görülmektedir. Ancak bu özelliklerin tümü ulus devletin sadece 'devlet' kısmıyla ilgilidir. Ulusal bilincin gelişimi ya da "ulus inşası" devlet inşasından farklı süreçler olarak kabul edilmektedir (Navari, 1981: 34-36). Bu anlayışın en yalın karşılığını İtalyan Devleti kurulduktan sonra Massimo d'Azeglio'nun parlamentoda; "İtalya'yı yarattık, şimdide İtalyanları yaratmalıyız" ifadesinde görebilmekteyiz (Hobsbawn, 1965: 63). Bu noktada ulus kavramının tanımlamasına baktığımızda ise temel olarak benzer noktaları içermekle birlikte çok farklı açıklamaların yapıldığını görebilmekteyiz. Örneğin Weber (1993: 172), ulusu kendini bağımsız bir devlet biçiminde ifade edebilen bir duygu birliği olarak tanımlarken; Emerson (1965: 97) toplumsal mirasın en önemli unsurlarına ortaklaşa sahip oldukları ve gelecekteki yazgılarının da ortak olduğu duygusuna sahip insanların oluşturduğu topluluk olarak tanımlamıştır. Gökalp (1976: 18) ulusu, 
"lisanca, dince, ahlakça, edebiyatça müşterek olan yani aynı terbiyeyi almış fertlerden mürekkep bulunan bir zümre"; Stalin (1976: 15) tarihsel olarak kurulmuş, kararlı bir dil, toprak, iktisadi yaşam ve kendi kültür ortaklığında dile getirilen ruhsal biçimlenme"; Mauss (2005:125) ise "maddi ve manevi bakımdan bütünleşmiş, sürekli ve istikrarlı bir merkezci iktidarı olan, sınırları belirli, bilinçli olarak bir devlete ve onun yasalarına bağlı sakinlerin kültür, zihniyet ve ahlak açısından göreli bir birliğe sahip olduğu bir toplum olarak" tanımlamıştır. Bu tanımlamalardan yola çıkarak ulus kavramını soy, dil, din, tarih, kültür birliği ve "öteki ya da düşman imajı" gibi faktörleri ulus kavramının görüngüleri olarak ele alabiliriz.

Ulus devletin oluşumu ile farklılaşan önemli konulardan biriside 'tebaa'nın yerine 'vatandaşlık' kavramının ikamesinin sağlanmasıyla birlikte hukuki normların ülkenin her tarafında eşit düzeyde uygulanmaya başlanmasıdır. Böylelikle ülke içindeki tüm klan ya da kast biçimdeki sadakat ve toplumsal birliği sağlayan sosyal-kültürel ilişkiler yok edilmiş, sadakatın ve toplumsal birliğin sadece ulusa ait olduğu ideolojisi yayılmıştır. Siyasi otorite, ayrıca yaratmış olduğu ulusal bürokrasi, eğitim ve ulusal ordu sayesinde farklı bölgelerden ve sınıflardan gelen vatandaşlarını ortak idealler, semboller ve ayinler doğrultusunda sosyalleştirme yoluna gitmiştir. Böylelikle milli sınırlar içindeki demografik yapı benzeşme yoluna gitmiş ve diğer ülkelerin demografik yapılarından farklılaşmaya başlamıştır. Benzer olanlar belli bir kimliğin taşıyıcıları olarak biz, farklı olanlar ise onları oluşturmaya başlamıştır (Held, 2001: 85; Tilly 2001: 202).

Güçlü bir ulus devletin varlığından söz edebilmek için güçlü bir ulusal entegrasyondan söz etmek gerekir. Ulusal entegrasyondan kasıt aynı tarihi, dili, gelenekleri ya da kültürü paylaşan insanların sadece bir 'halk' değil aynı zamanda bir 'ulus' olduklarının farkına var(dır)ma anlamında bir yaratmadır. Ulusal entegrasyonun gerçekleşmesini engelleyen her faktör, ulusal birliğin oluşumuna zarar verir. Bu nedenle, ulus devletler tarih sahnesine çıktıkları andan itibaren ulusal sınırları içinde bulunan nüfusu türdeşleştirme siyaseti gütmüşlerdir. Nüfusun kültürel bir türdeşliğe sahip olması idari aygıtın görünür olmasına nüfus içinde dayanışmanın ve sadakatin teminine, yöneten-yönetilen ilişkisinde iletişimin daha rahat gerçekleşeceğine inanılmaktadır. Bu ko- 
nuda Strayer, "kültürel bakımdan türdeş bir yapıya sahip toplumların parçalı, heterojen bir yapıya sahip olan toplumlara göre daha güçlü bir ulus devlet oluşturması açısından farklılık olduğunu belirtir. Bunun en büyük nedenini ise parçalı ve heterojen yapıya sahip toplumlarda devlete yönelik sadakatin parçalı bir nitelik kazanmasına bağlar. Bu nedenden dolayı ulusal birliği tehdit eden temel faktörleri genel hatlarıyla "etnik azınlıklar, dinsel gruplar, dil, akrabalık ve bölgecilik" faktörleri olarak belirtmektedir" (Strayer, 1989'dan akt. Tilly, 2001: 176-177). Benzer şekilde ulus devletin varlığının devamlılığında ulusal entegrasyonun başarılı bir şekilde sürdürülmesinin gerekliliğine ve ulusal birlik duygusunun önemine dikkat çeken Smith (2002) ise "toplumda etnik, dilsel veya dinsel bölünmelerin ulusal birliği tehdit eden temel faktörler olarak nitelemektedir".

Kısaca değindiğimiz bu nedenlerden dolayı modernleşme süreciyle birlikte ulus devletler, ulusal sınırlar içinde dil, eğitim, yasa ve iktisat politikaları açısından kendi vatandaşlarının yaşamını standartlaştırma yoluna gitmiştir. Bunun yanında siyasi otorite, yaratmış olduğu ulusal bürokrasi, eğitim ve ulusal ordu sayesinde farklı bölgelerden ve sınıflardan gelen vatandaşların ortak idealler doğrultusunda sosyalleştirme yoluna gitmişlerdir. Bu nedenle Giddens, ulus devleti "power container" yani "güç kabı" olarak nitelendirmiştir. Bununla devletin ülke içinde bulunan tüm yerel farklılıkları eriterek bir üst kimlikte birleştirme gücünü kastetmektedir (Giddens, 2005: 164). Birch (1989: 36-37) ise devletin, bir takım kurumlar ihdas etmek suretiyle bireylerin geleneksel yaşam tarzlarını ve sadakat bağlarını süreç içinde zayıflatmaya ve ulusal kültürle bütünleştirmeye çalıştığını belirtmektedir. Billig (2002: 151) modernitenin siyasal aktörleri olarak tanımladığ1 ulus devletin "geleneksel, bölgesel, kültürel, dilsel ve etnik farklılıkları düzleştiren merkezi siyasal hükümetler” olmalarını getirdiğini belirtmektedir. Koşut olarak Guibernau (1997: 93) da modern bir olgu olarak ulus devletin toplumsal alandaki "safçı” yaklaşımını şu ifadelerle ortaya koyar: "Ulus devlet sinırları belirlenmiş, bir toprak parçası içinde yasal güç kullanma hakkına sahip yönetimi altındaki halkı türdeşleştirerek, ortak kültür, simgeler, değerler yaratarak, gelenekler ile köken mitlerini canlandırarak (kimi zaman uydurarak) birleştirmeyi amaçlayan bir tür devletin oluşumu ile tanımlanan, modern bir olgu- 
dur”. Görüldüğü üzere millet olma ve bunun şuuruna varma bilinçte köklü bir değişikliği getirdiği için ulus devletin kurucuları da bazı aygitlar kullanmak suretiyle bu bilinci hak katmanlarına yaymışladır. Dolayısıyla "ulus inşası" ya da "ulusun yaratılması" deyiş̧leri kültürel ve tarihsel olarak belli özellikler taşıyan halk kitlesinin ulus olduklarının şuuruna er(diril)meleri süreci olarak anlaşılmalıdır. Ancak toplumsalkültürel farklılıkların devlet aygıtı tarafından dönüştürüldüğü kabülü kaçınılmaz olarak hangi kültüre dönüştürüldüğü sorusunu akla getirmektedir ki; devletin sosyal zemininde yaşanmakta olan kültürlerden bağımsız yeni bir kültür oluşturması gerçekçi değildir. Öyle ise devlet siyasal varlığının taşıyıcısı olan kültüre dayanma ve farklı kültürel unsurlarını sözü edilen bu kültüre dönüştürme eğiliminde olacaktır. Bu durumda Kaya (2000: 145)'nın da belirttiği üzere ulus devletler genelde “...bir etnik kimlik, ortak bir geçmiş, ortak söylenceler ve anılar dizini, ulusal bir marş, ataların uğruna öldüğü toprak parçası, ulusal bir ekonomi ile birlikte yasal haklar ve ödevler bütünü gibi objektif unsurlar üzerine inşa edilmiştir”. Kaya'nın yapmış olduğu tanımda da açıkça görüldügü üzere etnik-kültürel farklılıklar arasında diğerlerine göre daha baskın olan ve genelde siyasal sistemin dayandığ toplumsal zemini teşkil eden tarihi kültürel bütünlüğün bir vakum oluşturarak diğer sosyal farklılıkları kendine yaklaştırdığı ve devletin de ulusal bütünlük kaygısıyla bu süreci desteklediği anlaşılmaktadır. Tanımın son kısmında yer alan ekonomik ve hukuksal haklardan söz edilmesi ulus devletlerin toplumsal değişme sürecinden bağımsız işlemediklerini; oluşumların başlangıçlarına ait otoriter niteliklerin demokratikleşme sürecine bağlı olarak bireysel yasal haklara dair kazanımlarla yumuşatıldığını göstermektedir. Fakat uluslar ve ulus devletler hakkındaki yazında ve söylemlerde bu değişim genelde göz ardı edilmekte; "tek tipleştiricilik" ulus devletlerin evrensel değişmez nitelikleri olarak sunulmaktadır. Ancak ulus, ulus devlet ve ulusal birlik gibi kavramlara dayalı geliştirilen açıklama ve uygulamaların ulus devletin, "ulus" tabanını başka bir değişle toplumsal yapısını oluşturan bireyler tarafından nasıl algılandığının açığa çıkartılması, "ulus kimlik, dil, din, eğitim, siyasi yapılaşma" konuları hakkında düşüncelerinin dikkate alınarak yeniden değerlendirilmeye alınması önemli bir konuyu içermektedir. Köktürk (2004: 44)' ün de ifade etmiş olduğu gibi 'kültürel tabanlardan gelen 
talepler doğrultusunda sosyo-politik bir yeniden yapılanmanın lüzumu ulus devletler için, siyasal yapılarını üzerine kurdukları toplumsal kültürel tabanın derinliklerine inerek kültürel yapılarını modern toplumsal koşullara uygun olarak yeniden üretmelerine bağlıdır. Bu süreçte egemenlikleri altındaki insan unsurunun özgün değerlerini ve çağın kültürünün getirdiği bireysel ve toplumsal dönüşüm, gelişim taleplerini göz ardı etmemelidirler. Aksi halde devletlerin söz konusu bireysel ve kültürel gelişme taleplerini görmezlikten gelme durumlarında çağın gereklilikleri karşısında yapısal erozyona uğramaları kaçınılmaz olacaktır".

\section{Ulus Devletin Toplumsal Temeli: Millet}

Ulus devletlerin toplumsal bağlamının açıklanması başka bir ifadeyle ulus-millet yapısının açıklanması oluşturucu ve birleştirici temel dinamiklerinin ortaya konularak toplumsal gelişim seyrinin belirlenmesi önem arz etmektedir. Bu konunun önemi esasında küreselleşme ve küreselleşmeye eşlik eden çokkültürcülük ideolojisinin geçerliliğinin ortaya konmasına katkı sağlayacaktır. Aynı zamanda çokkültürcülük ideolojisinin, ulus devleti var eden, toplumsal dinamiğini oluşturan sosyal bütünleşmeyi ve ulusal birliği sağlayan "millet"in iç dinamiklerini nasıl ve hangi ölçüde dönüştürdügünü de açığa çıkartacaktır. Böyle bir tespitin yapılması temelde modern bir olgu olarak karşımıza çıkan "tek tipleştirici” ulus devletin millet örgütlenmesinin temel yapıtaşlarında nasıl bir etki yarattığının açığa çıkartılmasını sağlayacaktır.

Milleti açılarken ve ulusal bütünlüğün temel dinamiklerini belirlerken temelde iki farklı yaklaşımın olduğu göze çarpmaktadır. Bunlardan ilki millet bütünlüğünü milliyet düşüncesine dayandırmaktadır. "Milliyet ise çeşitli etnik, dilsel, dini ya da sadece tarihsel temelleri olan bir kültürel cemaate atıfta bulunur" (Leca, 1998: 12). Dolayısıyla mensubu olunduğuna inanılan kültürel cemaat millet olmaktadır. Guehenno (1998: 15-16)'ya göre ulus/millet tanımlanırken öncelikle onun ne olmadığı belirlenmelidir. Bu bağlamda öncelikli olarak ulusun, sosyal, dinsel ve ırkçı bir grup olmadığı belirtilmelidir. Sosyal, dinsel, ırkçı boyuta indirgenemeyen ulusal bütünlüğü sağlayan bağ tarihsel verilerin tek biçimliliğidir. Bu çerçeveden hareketle ulusun "insanları ne oldukları temelinde değil, onların geçmişte ne ol- 
duklarına ilişkin sahip oldukları hatıranın temelinde" getirdiği anlaşı1maktadır. Güngör (1997: 78) "bir insan topluluğunu bir millet haline getirmek, her şeyden önce onları bir millet olduklarına inandırmakla mümkün" olduğunu belirtmektedir. Burada vurgulanan millet fertlerinin tarih şuurlarının bir kurgudan ibaret olduğu değil; aksine tarihsel derinliğin milletlerin toplumsal kaynaşmalarındaki işlevsel katkısının büyüklüğünün bu derinlikten yoksun olan toplumları onu inşa etmeye sevk ettiğidir. Weber (1993: 171) millet kavramına "belli bir grup insanda başka gruplara karşı belirli bir dayanışma duygusunun harekete geçirebileceği anlamına" geldiğini, dolayısıyla kavramın değerler dünyasına ait olduğunu belirtir. Öte yanda ulusal bilinç devlete bağlılığı da şekillendirmektedir. Ulus düşüncesi devlet topraklarında yaşayan kişilere hukuk ve siyaset aracılığı ile yeni bir aidiyet bilinci kazandırır. “...ortak köken, dil ve tarih anlayışı etrafında kristalleşen ulus bilinci, başka bir değişle aynı halka ait olma bilinci yönetilenleri tek bir siyasal kamunun vatandaşlarına birbirine karşı sorumluluk duyan üyelere dönüştürür" (Habermas, 2002: 21). Bu düşünsel çerçeveden hareketle milletin sadece devletle birey arasındaki siyasal sözleşmeden ve bu sözleşmenin doğurduğu haklar ve yükümlülük temelinde olmadığını tarihsel ve dilsel ortaklıklar temelinde oluştuğunu belirtebiliriz.

Millet olgusunun açıklanmasında ikinci yaklaşım onun modern toplumsal, ekonomik ve politik koşullarda temellendirmesine dayanmaktadır. Dolayısıyla millet "kapitalizm, sanayileşme, merkezi devletlerin kurulması, kentleşme, laikleşme gibi modern” (Özkırımlı, 1999: 98) dinamiklerin ürünü olarak ifade edilmektedir. Bu yaklaşımın temel savunucuları milleti bir arada tutan en büyük bağın uzmanlık donanımlarına bağlı olarak gelişen bilgisel/teknolojik yeterliliklerine bağ11 olarak geliştiğini ifade etmektedirler. $\mathrm{Bu}$ anlamda modern iletişim araçlarının kullandıkları dil ve ilettikleri mesajlarla ulusal bütünlüğe katk1 sağladığ hatta onu oluşturduğu kabul edilmektedir. ${ }^{1}$ Çizilen bu ilkesel çerçevede ulus devletlerin ulusal dil konusundaki titizlenmelerin ulusal dilin eğitim ve iletişim sistemindeki geçerliliğinden kaynaklanan kamusallığın dinsel, mezhepsel, etnik, cinsel, sınıfsal bağlılık-

1 Bu konuda ayrıntılı bir tartışma için bkz. Gellner (1983) Nations and Nationalism, Blacwell, Oxford. 
ların üstünde bir aidiyet oluşturmasından kaynaklanmaktadır. Ulusal dilin genelde standart kültürün dili olması, dil aracılığı ile gerçekleşen katılımlarla standart kültürün kapsamının genişlemesi kadar yapısının dönüşmesine ve esnekleşmesine neden olmaktadır. John Stuart Mill (1993: 392) "kardeşlik hissine sahip olmayan bir halk arasında özellikle farklı dillerde okuyup yazıyorlarsa temsili hükümetin işlemesi için gerekli olan birleşik kamuoyu oluşamaz" dediğinde muhtemelen bunu kastediyordu. "Fakat dil ortaklığı barışçı birlikteliği sağlamak içinde ne olmazsa olmaz bir koşuldur ne de tek başına yeterlidir. Belçika, İsviçre, Kanada, Britanya örnekleri farklı diller konuşan bölgesel olarak yoğunlaşmış etno-kültürel grupların (ulusal grupların ) aynı siyasal toplum içerisinde barışçı bir biçimde birlikte yaşayabileceklerini ve ortak bir milliyet duygusuna sahip olabileceklerini göstermektedir. Diğer yandan aynı dili konuşmak Sırplar, Hırvatlar ve Bosnalılar, Avusturyalılar ve Almanlar, İngilizler Amerikalılar ve İrlandalılar, Danimarkalılar ve Norveçliler ve Ürdünlüler ve Iraklılar arasında ortak bir duygu yaratmıyor. Daha da ilginci, Almanca konuşan Alsaslılar Almanlarla ortak bir ulusal duyguyu paylaşmıyorlar, fakat Fransızlarla paylaşıyorlar" (Weber, 1994 akt. Tok, 2003: 301). Bu nedenden dolay1 "farkl1 etno kültürel grupların farklılıklarını koruyup ifade ederlerken, aynı siyasal toplum içerisinde barışçı bir biçimde birlikte olup olamayacaklarına ve ortak bir ulusal kimlik geliştirip geliştiremeyeceklerine karar vermede kesin bir ölçüt görevi” (Tok, 2003: 302) göremeyeceği ifade edilmektedir.

Leca, ulus toplumsal bütünleşmenin bir yüksek kültürün siyasal otorite tarafından desteklenmesi sonucunda alt kültürlerin sözü edilen yüksek kültüre eklemlenmesi şeklinde gerçekleştiğini belirtir. Onun ifadesiyle “...hakim sosyolojik teoride ulus, aynı ekolojik alan üzerindeki kültürel, ekonomik ve siyasal sitemlerin çakışma süreçleriyle birlikte 'alt kültürlerin' standartlaştırılmış, homojen ve merkezi iktidar tarafindan desteklenen bir yüksek kültür ile bütünleşmesi olarak ele alınır" (Leca, 1998: 13). Smith (2002: 111) ise "modern koşullarda bir milletin varlığını toplumsal bütünlüğünün korunmasını birliktelik koşullarının yani, devlet organlarının ve toplumsal enerjinin uyumlu işletilmesine bağlı olduğunu" belirtmektedir. Dolayısıyla belirtilenlerden ulus toplumlarının bileşenlerinden yalnızca biri (köken veya vatandaş- 
lık) ile tanımlamalarının eksikliğini ortaya koymaktadır. Parçanın bütünü kapsamaması ilkesi uyarınca unsurlardan biri baz alınarak yapılacak ulusal bütünlük açıklamaları eksiklik taşımaya devam edecektir.

Bunların yanı sıra küreselleşmenin ve çokkültürcü politikaların etkisiyle son zamanlarda "devlet-toplum etkileşimi karmaşıklaşmış, toplumun hakim devlet ve tekil kültür temelinde yönetilmesi felsefesi 'meşruiyet krizi'ne neden olmuştur. Aynı zamanda kültürel farklılikların siyasal temsilleri gündeme gelmesiyle birlikte devlet-toplum ilişkilerinin yeniden düzenlenmesini içeren 'anayasa' ve 'anayasallık' odaklı akademik-politik tartışmalara neden olmaktadır" (İçduygu ve Keyman: 2004: 158). Bu tartışmalar yukarıda da söz etmiş olduğumuz gibi çokkültürlü bir devlette ortak vatandaşl1k statüsünün herkes için eşit vatandaşlık anlamına gelmemesinden kaynaklanmaktadır. Söz konusu siyasal toplum bir "çokkültürlü siyasal toplum olduğunda, vatandaşlığa ilişkin eşitlik, vatandaşlığın etnisite kültür ve milliyetteki farklılıkları görmezden gelerek tanımlanmasını değil, bunları tanıyıp kapsayacak bir biçimde tanımlanmasını gerektirir. Bir çokkültürlü devlet için uygun vatandaşlık kavrayışı tek ortak bir vatandaşlık değil, çokkültürlü bir vatandaşlık olacaktır. Bu yüzden çokkültürlü bir devlette vatandaşlığın bazı unsurları grup farkına dayalı olabilir ve eşit vatandaşlık azınlık, etnik ve ulusal gruplar için özel politika düzenlemeleri gerektirebilir" (Tok, 2003: 195).

\section{Ulusal Devlet İdealinin Temel İlkelerinin Sorgulanmasının Nedenleri}

Ulusal kimlik, uluslaşma ve ulus devlet süreçleri birbirinden bağımsız değildir. Hobsbawn (1995: 24) "milletin ancak belli bir modern teritoryal devletle "milli devlet"le ilişkilendirildiği kadarıla bir toplumsal birim" olduğuna inanmaktadır. Bu nedenle millet mefhumunu siyasal ve hukuki anlamda değerlendiren yaklaşımlar varsa da biz burada sosyolojik yaklaşımlara öncelik vermekteyiz. Bundan dolayı ulus devlet, bir toplumun siyasal çatısını oluştururken ulus ise bu siyasal çatının sosyolojik tabanı ile ilişkilidir. Ulusal kimlik ise söz konusu siyasal ve sosyal bütünleşmenin bir ifadesi olarak değerlendirilebilir. Bilindiği üzere 1980'ler öncesinde gerek modernleşme gerekse ulus devlet modeli üzerine yapılan tartışmalarda hakim anlayış, etnik kültüre 
dayanan, yerel, bölgesel ve alt-kültürel kimliklerin ulaşım ve iletişim kanallarının yaygınlaşması sonucunda zamanla törpüleneceği ve ulusu temsil eden tek bir üst kimliğin hakim olacağı yönündeydi. Bu nedenle ulus devlete adını veren hakim etnik grubun ulusçuluk ideolojisi de ülke sınırları içerisinde yaşayan "ulusal azınlık" ve farklı etnik grupların devlet politikaları aracılığı ile ortak bir ulusal kimliği benimseyerek asimile olması ya da dışlanarak etkisiz hale getirilmesi, göçe zorlanmas1, hatta temizlenmesini savunmaktadır (Deutsch, 1966; Connor, 1972; Gelner, 1983; Hobsbawn, 1995; Mann, 2001). Ancak 1990'lardan itibariyle etnisitenin siyasallaşması ve etnik ulusçuluğun yeniden canlanması, çokkültürlülük politikalarının yaygınlaşması ile birlikte ulus devletin kendi coğrafi sınırları içinde üst kimlikle ve kültürle tamamıyla özdeşlesen, alt kültürlerin zamanla asimile olarak yok olduğu bir siyasal ve toplumsal sistemin var olamayacağını göstermiştir. $\mathrm{Bu}$ nedenle "ulusçuluğun kutsallaştırdığı homojen ulus ve tek kollektif kimlik, ulusal birliği sağlayan temel faktörlere bağlı kabullerin yeniden tartış1lması" gündeme gelmiştir (Raanan, 1991: 130). Söz konusu tartışmalardan ve gelişmelerden dolayı araştırma Türkiye'de yaşayan bireylerin ulus, ulus devlet ulusal kimliğe yönelik tutumlarını analiz edilebilmesi; toplumsal birlik ve beraberliğe yönelik bakış açılarının ortaya çıkarılabilmesi için "Ulusal Birlik Algısı Ölçeği”nin geliştirilmesi amacıyla yapılmıştır. Böylelikle Türk toplumu açısından hangi konuların ulusal birliği sağlayan/ tehdit eden temel meseleler kapsamında ele alınabileceğinin ortaya konulması sağlanabilecektir.

\section{Yöntem}

\section{Çalışma Grubu}

Araştırmanın çalışma grubunu, Sakarya ili sınırları içerisinde yaşamakta olan farklı kültürel yapılara ve etnik kökene sahip 293 katılımcı oluşturmaktadır. Denemelik olarak belirlenen "Ulusal Birlik Ölçeği" çalışma grubuna uygulanarak elde edilen verilerle ölçeğin çözümlenmesi yapılmıştır. Ölçek çalışmasına katılan bireylerin birtakım özelliklerine göre dağılımı Tablo 1'de verilmiştir. 
Tablo 1. Katılımcı bireylerin cinsiyet, yaş, eğitim durumu, meslek ve etnik grup değişkenlerine göre dağılımı

\begin{tabular}{|c|c|c|c|}
\hline Özellik & Grup & $\mathbf{N}$ & $\%$ \\
\hline \multirow{2}{*}{ Cinsiyet } & Kadın & 156 & 53.2 \\
\hline & Erkek & 137 & 46.8 \\
\hline \multirow{9}{*}{ Yaş } & $18-24$ & 44 & 15.0 \\
\hline & $25-29$ & 42 & 14.3 \\
\hline & $30-34$ & 47 & 16.0 \\
\hline & $35-39$ & 45 & 15.4 \\
\hline & $40-44$ & 37 & 12.6 \\
\hline & $45-49$ & 27 & 9.2 \\
\hline & $50-54$ & 26 & 8.9 \\
\hline & $55-59$ & 13 & 4.4 \\
\hline & 60 ve üzeri & 12 & 4.1 \\
\hline \multirow{9}{*}{$\begin{array}{l}\text { Eğitim } \\
\text { durumu }\end{array}$} & Okuma yazma bilmiyor & 8 & 2.7 \\
\hline & Yalnızca okur yazar & 6 & 2.0 \\
\hline & İlkokul mezunu & 46 & 15.7 \\
\hline & Ortaokul mezunu & 34 & 11.6 \\
\hline & Ortaokul dengi meslek okul mezunu & 9 & 3.1 \\
\hline & Lise mezunu & 51 & 17.4 \\
\hline & Lise dengi meslek okulu mezunu & 21 & 7.2 \\
\hline & Yüksekokul/Üniversite mezunu & 84 & 28.7 \\
\hline & Lisansüstü & 34 & 11.6 \\
\hline \multirow{8}{*}{ Meslek } & Ev Hanımı & 68 & 23.2 \\
\hline & Memur & 58 & 19.8 \\
\hline & Serbest Meslek & 27 & 9.2 \\
\hline & Esnaf/Zanaatkar & 32 & 10.9 \\
\hline & İşçi (Vasıfl1/Vasıfsız) & 41 & 14.0 \\
\hline & Toprak Sahibi veya Çiftçi & 7 & 2.4 \\
\hline & İşsiz & 16 & 5.5 \\
\hline & Diğer & 44 & 15.0 \\
\hline \multirow{12}{*}{$\begin{array}{l}\text { Etnik } \\
\text { grup }\end{array}$} & Türk & 52 & 17,7 \\
\hline & Kürt & 27 & 9,2 \\
\hline & Arnavut & 25 & 8,5 \\
\hline & Tatar & 14 & 4,8 \\
\hline & Abhaz & 15 & 5,1 \\
\hline & Çerkes & 31 & 10,6 \\
\hline & Pomak & 16 & 5,5 \\
\hline & Arap/Sudanl1 & 7 & 2,4 \\
\hline & Roman & 1 & 0,3 \\
\hline & Boşnak & 23 & 7,8 \\
\hline & Gürcü & 27 & 9,2 \\
\hline & Laz & 55 & 18,8 \\
\hline \multicolumn{2}{|l|}{ Toplam } & 293 & 100 \\
\hline
\end{tabular}


Tablo 1 de görülüğg̈ü üzere katılımcıların \%53,2'si kadın, \%46,8'ini erkek oluşturmaktadır. Araştırmaya katılanların en çok sırasıyla \%16.0'i 30-34 ve \%15.0'i 18-24 yaş aralığında, en az sırasıyla \%4.1 60 ve üzeri, \%4.4 55-59 yaş aralığına sahip bireylerden oluştukları görülmektedir. Eğitim durumu değişkenine göre katılımcı bireylerin en çok sırasıyla \%28,7'sinin yüksekokul/üniversite mezunu, \%17,4'ün lise mezunu, \%15,7'sinin ilkokul mezunu, lisansüstü ve ortaokul mezunu ise \%11, 6'dir. Okuryazar olmayan $(\% 2,7)$, yalnızca okuryazar $(\% 2,0)$ ve ortaokul dengi meslek okul mezunu $(\% 3,1)$ olan katılımcıların oranı oldukça düşüktür. Araştırmaya katılan bireylerin mesleklerine göre dağılımları ise en az \%2,4 ile toprak sahibi veya çiftçi, işsiz $\% 5,5$ ve serbest meslek $\% 9,2$ diğer $\% 15,5$ meslek gruplarıdır. Katılımcıların ağırlıklı olarak ev hanımı $(\% 23,2)$ ve memur $(\% 19,8)$ meslek gruplarında yer aldıkları görülmektedir. Katılımcıların etnik gruplarına göre dağılımları en çok Türk $(\% 17,7)$, Çerkes $(\% 10,6)$, Gürcü $(\% 9,2)$, Kürt $(\% 9,2)$ ve Arnavut $(\% 8,5)$ oluşturmaktadır. Arap $(\% 2,4)$ ve Roman $(\% 0,3)$ etnik gruplarından olan katılımcıların oranı ise oldukça düşüktür.

\section{Veri Toplama Aracı}

Türkiye'deki toplumsal birlik ve beraberliği güçlendirdiği veya zarar verdiği ileri sürülen birtakım durumlar belirlenerek bireylerin ulusal birliğe yönelik bakış açılarını ölçmek için hazırlanan "Ulusal Birlik Algısı Ölçeği”ni geliştirme çalışmalarında şu adımlar izlenmiştir:

Öncelikli olarak maddeleri belirlemek amaciyla ulus devlet, ulus devletin bileşenlerini oluşturan temel unsurlarla ilgili alan yazın taranmış ve gerekli incelemeler yapılmıştır. Yapılan bu incelemede bireylerin ulusal birliğe yönelik bakış açılarını belirlemeye yönelik bir ölçme araçlarının olmadığı tespit edilmiştir. Daha sonra literatür bilgilerinden de faydalanarak araştırmacı ve bu alanda uzman 4 kişi ile madde havuzuna bireylerin ulusal birliğe yönelik bakış açılarını ortaya çıkarıcı 43 durum yazılmıştır. Yazılan bu ifadelerin anlaşılırlığını, ölçülmek isteneni ölçme yeterliğine ve niteliğine sahip olma durumlarını değerlendirmek üzere daha önce ölçek geliştirme konusunda çalışmış 3 uzman akademisyenle madde havuzunda ifadeler üzerinde birlikte çalışılmıştır. Onlardan gelen dönütler doğrultusunda gerekli düzeltme 
işlemleri yapılarak 43 maddelik ulusal birlik ölçeği ön deneme uygulamasına hazır hale getirilmiştir. Bu ifadelerden 4'ü olumsuz iken, 39'u ise ulusal birliğe yönelik olumlu tutumları yansitmaktadır. 43 ulusal birlik ifadesi alt alta sıralanmış ve ifadelerin karşısına ulusal birli$\breve{g i}$ " $5=$ çok tehdit eder, $4=$ tehdit eder, 3=kararsızım, 2=tehdit etmez, $1=$ hiç tehdit etmez" ş̧eklinde derecelendirilmiştir. Olumsuz ifadelerin bulunduğu maddeler ise bunun tam tersi şeklinde puanlandırılmıştır. Ayrıca ölçeğin başına; ölçeğin amacı, ölçekteki madde sayısı, yanıtlama biçimi hakkında bilgi veren bir yönerge konulmuştur.

\section{Verilerin Toplanmast ve Analizi}

Denemelik olarak hazırlanan ölçeğin geçerlik ve güvenirlik sınamas1nı yapmak amacıyla Sakarya ili sınırları içerisinde yaşayan 293 katılımcı bireye araştırmacı tarafından ön deneme uygulaması yapılmıştır. Elde edilen veriler üzerinden geçerlik ve güvenirliğe kanıt sağlamak amacıyla iç tutarlılık güvenirlikleri (Alfa), madde test korelasyonları, alt $\% 27$ ve üst $\% 27$ 'lik grupların madde puanlarının karşılaştırılmasına ilişkin t-testi, Kaiser-Meyer Olkin (KMO) katsayısı ve Barlett Küresellik Testi (Barlett Test of Sphericity) ve temel bileşeler analizi yapılmıştır. Elde edilen veriler üzerinden analizler yapılırken SPSS.15 paket programı kullanılmıştır.

\section{Bulgular}

Bu bölümde "Ulusal Birlik Algısı Ölçeği”nin geliştirilmesi amacıyla yapılan geçerlik ve güvenirlik sınamalarına ilişkin bulgulara dayalı olarak yapılan yorumlara yer verilmiştir.

\section{Geçerlikle İlgili Bulgular}

Öncelikli olarak ölçeğin yapı geçerliğine uygunluğu için iç tutarlığına bakılmıştır. Yapılan analizde madde-toplam korelasyonu oldukça düşük çıkan 43 maddelik ölçekten 4 madde (10, 13, 22 ve 43. maddeler) ölçekten çıkarılmıştır. Daha sonra geri kalan 39 maddelik ölçeğin faktör analizine uygun olup olmadığını belirleyebilmek amacıyla KaiserMeyer Olkin (KMO) ve Barlett Küresellik Testi yapılmıştır. Tablo 2'de KMO ve Barlett Küresellik testine ilişkin istatistikler verilmiştir. 
Tablo 2. KMO ve Barlett Testi

Kaiser-Meyer-Olkin (KMO)

.837

Ki-kare

5033.609

Barlett Testi

sd

741

p

.000

KMO verilerin ve örneklem büyüklüğünün seçilen analize uygun ve yeterli olup olmadığını belirlemede kullanılan istatistiksel bir yöntemdir. KMO katsayısı 1'e yaklaştıkça verilerin analize uygun olduğu, 1 olmasında ise mükemmel bir uyum olduğu anlamına gelir. Yapılan analiz sonucunda KMO değeri .837 olarak bulunmuştur. Parametrik yöntemi kullanabilmek için, ölçülen özelliğin evrende normal dağ 11 lı göstermesi gerekir. Barlett Sphericity testi verilerin çok değişkenli normal dağılımdan gelip gelmediğini kontrol etmek için kullanılabilecek istatistiksel bir tekniktir. Bu test sonucunda elde edilen ki-kare $(\chi 2)$ test istatistiğinin anlamlı çıkması verilerin çok değişkenli normal dağılımdan geldiğinin göstergesidir. Çalışma içerisinde yapılan analiz sonucunda Barlett küresellik testi anlamlı bulunmuştur $(\chi 2=5033.609 ; p<0.01)$. KMO testi ölçüm sonucunun 0.60 ve daha üstü, Barlett küresellik testi sonucunun da istatistiksel olarak anlamlı olması gerekmektedir (Jeong, 2004). Yapılan istatistikler bu temel varsayımları oldukça iyi düzeyde karşıladığından faktör analizi yapılabileceği kanısına ulaşılmıştır.

Bireylerin ulusal birlik algılarına anlamlı bir yapıya ulaşabilmek ve hazırlanan ölçeğin geçerliğini belirlemek için kapsam geçerliği ve yap1 geçerliği sınamaları yapılmıştır. Kapsam geçerliliği için ulusal birliğe yönelik yazılan ifadelerinin belirlenmesi aşamasında uzman görüşlerine başvurulmuştur. $\mathrm{Bu}$ ifadeler belirlenirken başvurulan uzman görüşleri kapsam geçerliliğini için uygun ve yeterli kabul edilmiştir. Yapı geçerliliği sınaması için temel bileşenler analizinden varimax döndürme tekniği kullanılmış ve ölçeğin özdeğeri 1.00'den büyük dört faktörlü bir yapıya sahip olduğu belirlenmiştir. Şekil 1'deki yamaçbirikinti grafiğine göre de eğimin dört faktörden sonra sabitlendiği görülmektedir. 
Şekil 1. Yamaç-Birikinti Grafiği

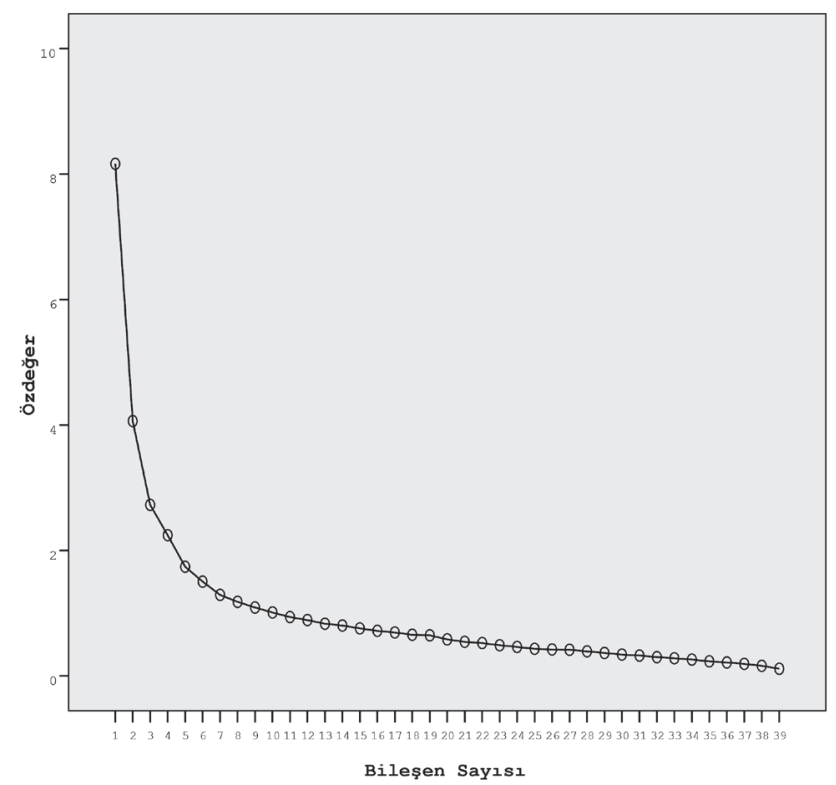

Çizgi grafiğine göre yüksek ivmeli, hızlı düşüşlerin yaşandığı eğim önemli sayıda faktör sayısına işaret etmektedir. Şekil 1'de görüldüğü gibi, eğimin dördüncü faktörden sonra sabitlenmeye başladığından faktör sayısı dört olarak belirlenebilir. Ayrıca, ölçeğin geliştirilmesi sürecinde belirlenen teorik yapıdan beklenen faktör sayısı ile de uyumlu olduğundan kabul edilebilir bulunmuştur.

Örneklem büyüklüğü dikkate alınarak (Şencan, 2005) hem de temel bir kural olarak her bir değişkenin yük değerinin 0.32 'den büyük olması ilkeleri (Tabachnick ve Fidel, 2001) ve maddelerin binişiklik durumu dikkate alınarak yapılan faktör analizi sonucunda, hiçbir faktörde yer almayan ya da birden çok faktörde birbirinden ayırt edilemeyecek kadar yakın yükler alan maddeler $(4,9,14$ ve 16 . maddeler) analizden teker teker çıkarılarak analiz tekrarlanmıştır. Çıkarılan maddelerden sonra da ölçeğin dört faktörlü yapısında herhangi bir değişim olmamıştır. Bahsi geçen maddeler dışarıda bırakılarak yapılan analizlerden sonra elde edilen faktörlerin açıkladığı varyanslara ilişkin bulgular Tablo 3'de verilmiştir. 
Tablo 3. Faktörlerin açıkladığı varyanslara ilişkin elde edilen bulgular

\begin{tabular}{cccc}
\hline Faktör & Özdeğer & Varyans Yüzdesi & Yığılmalı Varyans Yüzdesi \\
\hline 1 & 7.62 & 21.78 & 21.78 \\
\hline 2 & 3.72 & 10.63 & 32.41 \\
\hline 3 & 2.53 & 7.24 & 39.65 \\
\hline 4 & 2.18 & 6.23 & 45.88 \\
\hline
\end{tabular}

Tablo 3 incelendiğinde, toplamda açıklanan \%45.88'lik varyansın \%21.78'ini birinci faktör tarafından açıklanırken, geriye kalan faktörlerin açıkladıkları toplam varyansın sırasıyla \%10.63'ünü ikinci faktör, \%7.24'ünü üçüncü faktör ve \%6.23"ünü ise dördüncü faktör açıklanmaktadır. Tek faktörlü desenlerde açıklanan toplam varyansın asgari \%30 olması yeterli kabul edilebilirken (Büyüköztürk, 2006), çok faktörlü desenlerde ise bu oranın \%41'in üzerinde olması beklenir (Kline, 1994). Buna göre açıklanan toplam varyansın iyi ve yeterli düzeyde olduğu söylenebilir. Ölçeğin faktör analizi yapılarak elde edine faktör deseni, faktör yük değerleri ve ortak faktör varyansları Tablo 4'de gösterilmiştir.

Tablo 4. Faktör analizi sonucunda maddelere ilişkin elde edilen bulgular

\begin{tabular}{|c|c|c|c|c|c|}
\hline \multirow{2}{*}{ Madde No } & \multirow{2}{*}{$\begin{array}{c}\text { Faktör Ortak } \\
\text { Varyansı }\end{array}$} & \multicolumn{4}{|c|}{ Döndürme Sonrası Yük Değeri } \\
\hline & & Faktör-1 & Faktör-2 & Faktör-3 & Faktör-4 \\
\hline UB34 & .725 & .834 & & & \\
\hline UB35 & .704 & .831 & & & \\
\hline UB36 & .670 & .803 & & & \\
\hline UB37 & .678 & .796 & & & \\
\hline UB31 & .494 & .675 & & & \\
\hline UB33 & .494 & .648 & & & \\
\hline UB32 & .439 & .629 & & & \\
\hline UB29 & .676 & & .793 & & \\
\hline UB30 & .668 & & .791 & & \\
\hline
\end{tabular}




\begin{tabular}{|c|c|c|c|c|}
\hline UB28 & .646 & .766 & & \\
\hline UB25 & .332 & .549 & & \\
\hline UB24 & .437 & .524 & & \\
\hline UB18 & .373 & .487 & & \\
\hline UB17 & .256 & .454 & & \\
\hline UB23 & .311 & .436 & & \\
\hline UB26 & .195 & .426 & & \\
\hline UB27 & .282 & .395 & & \\
\hline UB39 & .640 & & .718 & \\
\hline UB40 & .652 & & .678 & \\
\hline UB41 & .509 & & .651 & \\
\hline UB38 & .648 & & .650 & \\
\hline UB7 & .451 & & .602 & \\
\hline UB5 & .418 & & .578 & \\
\hline UB42 & .474 & & .573 & \\
\hline UB8 & .381 & & .573 & \\
\hline UB6 & .344 & & .490 & \\
\hline UB3 & .387 & & .475 & \\
\hline UB19 & .474 & & & .645 \\
\hline UB1 & .388 & & & .602 \\
\hline UB15 & .453 & & & .580 \\
\hline UB2 & .402 & & & .565 \\
\hline UB21 & .304 & & & .516 \\
\hline UB20 & .299 & & & .512 \\
\hline UB12 & .220 & & & .462 \\
\hline UB11 & .229 & & & .444 \\
\hline
\end{tabular}

Tablo 4'de görüldüğü gibi Ulusal Birlik Algısı Ölçeği'ndeki maddelerin yedisi birinci faktörde $(31,32,33,34,35,36$ ve 37 . maddeler), onu ikinci faktörde $(17,18,23,24,25,26,27,28,29$ ve 30. maddeler), onu üçüncü faktörde $(3,5,6,7,8,38,39,40,41$ ve 42. maddeler) ve sekizi dördüncü faktörde $(1,2,11,12,15,19,20$ ve 21 . Maddeler toplanmıştır. Faktörlerde toplanan maddelerin ifade ettiği anlamlara bakılarak birinci faktörün Batılılaşma ve Modernleşme 1 ikinci faktörün Ulusal Kimlik-Homojenlik, üçüncü faktörün Adalet ve Hakkaniyet ve dördüncü faktörün ise Sosyo-Ekonomik, Kültürel-Dini Farklılık adlandırılabileceği söylenebilir. Ölçeği oluşturan maddelere ilişkin faktör yük değerleri birinci faktörde .63 ile .83 arasında, ikinci faktörde .40 ile .79 arasında, üçüncü faktörde .48 ile .72 arasında ve dördüncü faktörde ise .44 ile .65 arasında değişmektedir. 
$\mathrm{Bu}$ değerlere göre faktör yük değerlerinin yeterli düzeyde iyi olduğu görülmektedir (Tabachnick ve Fidel, 2001). Tüm bu bulgular ölçeğin tatmin edici düzeyde yapı geçerliğine sahip olduğuna ilişkin kanıt olduğu söylenebilir.

\section{Madde Analizi ve Güvenirliğe İlişkin Bulgular}

Ölçeğin faktör düzeyindeki yapısını ve toplamdaki durumunu görmek amacıyla katılımcıların her bir maddeden aldıkları puanlarla faktör toplam puanları ve ölçek toplam puanları arasındaki düzeltilmiş madde toplam korelasyonları ve her bir madde için alt ve üst grupların karş1laştırılması yapılmıştır. Bunun yanı sıra, yine her faktör içerisinde ve toplam puanlar üzerinden güvenirlik katsayıları da hesaplanmış ve sonuçlar Tablo 5'de verilmiştir. Test-tekrar test güvenirlik çalışmaları ise yine sakarya ili sınırları içerisinde bulunan \%55.7'si kadın, \%43.3'ü erkek ve yaşları 18 ile 70 arasında (yaş ortalaması=16,43) değişen 97 kişi üzerinde yapılmıştır.

Tablo 5. Ölçeğe ilişkin madde analizi ve güvenirlik sonuçları

\begin{tabular}{|c|c|c|c|c|c|}
\hline & $\begin{array}{c}\text { Madde } \\
\text { No }\end{array}$ & $\begin{array}{l}\text { Madde-Toplam } \\
\text { Korelâsyonu }^{1}\end{array}$ & $\begin{array}{c}\mathbf{t} \\
(A \mid t \% 27-U ̈ s t \% 27)^{2}\end{array}$ & $\begin{array}{l}\text { İç Tutarlılık } \\
\text { Güvenirlik } \\
\text { Katsayısı* }\end{array}$ & $\begin{array}{c}\text { Test- } \\
\text { Tekrar Test } \\
\text { Güvenirliği }\end{array}$ \\
\hline \multirow{7}{*}{ 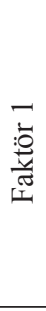 } & UB31 & .593 & $7.830 * * *$ & \multirow{7}{*}{.884} & \multirow{7}{*}{.897} \\
\hline & UB32 & .576 & $6.161 * * *$ & & \\
\hline & UB33 & .590 & $6.568 * * *$ & & \\
\hline & UB34 & .774 & $7.763 * * *$ & & \\
\hline & UB35 & .752 & $8.103 * * *$ & & \\
\hline & UB36 & .717 & $8.027 * * *$ & & \\
\hline & UB37 & .722 & $8.616 * * *$ & & \\
\hline \multirow{10}{*}{ 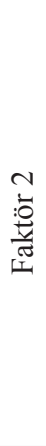 } & UB17 & .363 & $4.559 * * *$ & \multirow{10}{*}{.744} & \multirow{10}{*}{.877} \\
\hline & UB18 & .393 & $8.273 * * *$ & & \\
\hline & UB23 & .432 & $8.391 * * *$ & & \\
\hline & UB24 & .522 & $11.076 * * *$ & & \\
\hline & UB25 & .494 & $7.260 * * *$ & & \\
\hline & UB26 & .415 & $6.665 * * *$ & & \\
\hline & UB27 & .326 & $5.583 * * *$ & & \\
\hline & UB28 & .608 & $11.785 * * *$ & & \\
\hline & UB29 & .635 & $12.777 * * *$ & & \\
\hline & UB30 & .623 & $11.551 * * *$ & & \\
\hline
\end{tabular}




\begin{tabular}{|c|c|c|c|c|c|}
\hline \multirow{10}{*}{ 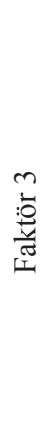 } & UB3 & .403 & $7.685^{* * *}$ & \multirow{10}{*}{.834} & \multirow{10}{*}{.854} \\
\hline & UB5 & .458 & $7.199 * * *$ & & \\
\hline & UB6 & .376 & $5.227 * * *$ & & \\
\hline & UB7 & .557 & $6.584 * * *$ & & \\
\hline & UB8 & .484 & $5.597 * * *$ & & \\
\hline & UB38 & .641 & $6.640 * * *$ & & \\
\hline & UB39 & .657 & $6.108 * * *$ & & \\
\hline & UB40 & .661 & $5.920 * * *$ & & \\
\hline & UB41 & .598 & $6.374 * * *$ & & \\
\hline & UB42 & .509 & $3.822 * * *$ & & \\
\hline \multirow{8}{*}{ 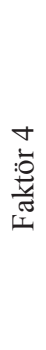 } & UB1 & .473 & $5.682 * * *$ & \multirow{8}{*}{.725} & \multirow{8}{*}{.845} \\
\hline & UB2 & .344 & $5.731 * * *$ & & \\
\hline & UB11 & .334 & $4.781 * * *$ & & \\
\hline & UB12 & .358 & $5.236 * * *$ & & \\
\hline & UB15 & .481 & $7.172 * * *$ & & \\
\hline & UB19 & .524 & $6.123 * * *$ & & \\
\hline & UB20 & .398 & $7.030 * * *$ & & \\
\hline & UB21 & .419 & $5.910 * * *$ & & \\
\hline
\end{tabular}

* Ölçeğin tamamına ilişkin iç tutarlılık güvenirlik katsayısı .863 , test-tekrar test güvenirliği ise .927 olarak bulunmuştur.

${ }^{1} \mathrm{n}=293 \quad{ }^{2} \mathrm{n} 1-\mathrm{n} 2=79 \quad * * * \mathrm{p}<.001$

Tablo 5 incelendiğinde, ölçekte yer alan tüm maddeler için madde-toplam test korelâsyonlarının .33 ile .77 arasında değerler aldığı ve t-değerlerinin anlamlı $(\mathrm{p}<.001)$ olduğu belirlenmiştir. Bu değerler ölçekteki maddelerin güvenirliklerinin yüksek olduğunu ve benzer davranışları temsil ettiğini göstermektedir. Ölçeğin güvenirliğine ilişkin olarak iç tutarlıklık katsayısı .86 olarak hesaplanmıştır. Bu değer ölçeği oluşturan maddelerin birbirleriyle tutarlı olduğunu göstermektedir. Ayrıca ölçekteki maddelerden her biri sıra ile ölçekten çıkarılarak yapılan denemelerde 0.86 olarak hesaplanan iç tutarlılık katsayısında bir yükselme olmadığından, güvenirlik çalışmaları sonucunda herhangi bir madde ölçekten çıkarılmamıştır (Özdamar, 1997). Ayrıca her bir alt faktör için ayrı ayrı iç tutarlılık güvenirlik katsayıları da hesaplanmıştır. Ölçeğin tümüne ait iç tutarlılık güvenirlik katsayısı .86, birinci faktöre ilişkin güvenirlik katsayı .88, ikinci faktöre ilişkin güvenirlik katsayıs1 .74, üçüncü faktöre ilişkin güvenirlik katsayısı .83 ve dör- 
düncü faktöre ilişkin güvenirlik katsayısı ise .73 olarak hesaplanmıştır. Ölçeğin tümüne ait test-tekrar test güvenirlik katsayıs1 .927 , birinci faktör .897 , ikinci faktör .877 , üçüncü faktör .854 ve dördüncü faktör ise .845 olarak tespit edilmiştir. Tüm bu bulgular ölçeğin tatmin edici düzeyde güvenirliğe sahip olduğuna ilişkin kanıt olarak kullanılabilir.

\section{Sonuç ve Öneriler}

"Ulusal Birlik Algısı Ölçeği” bireylerin ulusal birliği sağlayan temel faktör ve değerlerini tespit etmek amaciyla geliştirilmiş dört alt boyuttan oluşan bir ölçme aracıdır. Bu boyutlar sırası ile batılılaşma ve modernleşme, ulusal kimlik-homojenlik, adalet hakkaniyet, sosyoekonomik, kültürel-dini farklılık boyutlarıdır. Batılılaşma-Modernleşme boyutu, modern çağın hakim siyasal örgütlenme biçimi olarak karşımıza çıkan ulus devletin modernleşme süreciyle birlikte getirdiği toplumsal ve kültürel yapıdaki değişimin bireyler tarafından ulusal birliği sağlayan temel faktörler arasında olup olmadığını ölçmektedir. $\mathrm{Bu}$ alt boyutta toplamda 7 madde bulunmaktadır. Bu boyutta yer alan maddelerden bazıları şunlardır: "Toplum tarihi, kültürel bağların unutulması/giderek zayıflaması", "Batılılaşma/modernleşme ile kültürel/ yerel değerlerin giderek unutulması", "Hızlı teknolojik gelişmeler sonucu (internet, TV gibi) birebir ilişkilerin zayıflaması". Ulusal kimlik-homojenlik boyutu, ulus devlet inşa sürecinin temel dayanaklarını oluşturan tek dil, din ve bir üst kimlikte bütünleşen homojen toplum yapısı anlayışının bireyler tarafından ulusal birliği sağlayan temel faktörler arasında olup olmadığını ölçmektedir. Bu alt boyutta toplamda 10 madde bulunmaktadır. Bu boyutta yer alan maddelerden bazıları şunlardır: "Eğitimin sadece Türkçe dilinde verilmesi", "Her milletin örf, adetlerine, inançlarına göre özel gün ve bayramlarının resmi olarak kutlanmasına izin verilmesi”, "Ulusal kimliğin belli bir ırka-etnik kökene yönelik tasvir edilmesi”, Anayasada yapılacak değişiklikler ile "resmi dil Türkçedir" ifadesinin kaldırılması". Adalet-Hakkaniyet boyutu ise ulus devletin siyasal ve toplumsal inşa sürecinde tartışılmayan temel konular dışında dil, kültür, eğitim, din açısından farklı sosyal grupların eşitlik ve adalet çerçevesinde yönetilmenin ulusal birliği sağlayan temel faktör düzeyini ölçmektedir. Bu alt boyutta toplamda 10 madde bulunmaktadır. Bu boyutta yer alan maddelerden bazıları şunlardır: "Farklı milletten olan bireylerin sosyal, kültürel farklılıkla- 
rına saygı gösterilmemesi”, Bazı milletlere yönelik ayrımcı politikalar ve siyasi çalışmalar", "Toplumda adalete olan güvenin sarsılması"," Devlet yönetiminde din, dil, 1rk, mezhep, etnik köken, politik görüş vb. açıdan farklı gruplara mensup insanlara eşit ve adil muamele yapılmaması". Sosyo-Ekonomik, Kültürel ve Dini farklılık boyutu bireylerin ulus devlet içinde kamu kurum kuruluşlarında ve ülkenin coğrafi sınırları içerisinde var olan etnik-kültürel, ekonomik farklılıkların ulusal birliği sağlayan temel faktör düzeyini ölçmektedir. Bu alt boyutta toplamda 8 madde bulunmaktadır. Bu maddelerden bazıları şunlardır: "Türkiye'nin Doğu ile Batı Bölgeleri arasında sosyal-ekonomik imkânlar açısından farklılıklar görülmesi", "Farklı milletlerin kendi kültürel dillerini, sosyal kültürel değerlerini, adetlerini, müzikleri vb. içeren gazete, radyo, televizyon gibi yayın organlarının yaygınlaştırılması", "Bireylerin dini inancının gereği, istediği şekilde kamu kurumlarında giyinebilmesi”. Ölçekte yer alan toplam “4” madde ulusal birliğe yönelik olumsuz ifadeler içerdiğinden ters yönde puanlanmaktadır.

Ölçeğin alt boyutlarına ilişkin Alpha katsayılarının yüksek olması (Batılılaşma ve Modernleşme $=.88$, Ulusal Kimlik-Homojenlik=.74, Adalet Hakkaniyet=.83, Sosyo-Ekonomik, Kültürel-Dini Farkl111k=.73) alt boyutlarda yer alan maddelerin birbiriyle tutarlı olduğunu göstermektedir. Sonuç olarak geçerlilik ve güvenirlik çalışmalarına dayanılarak bu ölçeğin uygulanabilir olduğu söylenebilir.

Ulus devletin birliğini ve devamlılı̆̆ını sağlayan temel faktörlerin tartış1ldı̆̆ son dönemlerde özellikle farklı etnik kimliğe sahip bireylerin ulusal birliği sağlayan temel değer noktalarının açığa çıkartılması önem arz etmektedir. Böylelikle günümüzde ulusçuluğun modern demokratik bir devletin yapılanması ve toplumda çoğulcu pratiklerin yeşermesini tehdit eden özelliklerinin ön plana çıkması, Türkiye'de uygulanan azınlık politikalarının yarattığı sorunların tespit edilmesini kolaylaştıracağı gibi yeni kavramlar ışığında incelenmesini sağlayacaktır. 


\section{Kaynakça}

Birch, A. H. (1989). Nationalism and national integration USA: Unwin INC.

Billig, M. (2002). Banal milliyetçilik. (Çev. Cem Şişkolar). İstanbul: Gelenek Yayıncılık.

Büyüköztürk, Ş. (2006). Sosyal bilimler için veri analizi el kitabı. Ankara: Pegem Akademi Yayıncılık.

Connor, W. (1972). Nation building or nation destroying?. World politics, c. 24, 319-355.

Çokluk, Ö., Şekercioğlu, G. ve Büyükötürk, Ş. (2010). Sosyal bilimler için çok değişkenli istatistik. Ankara: Pegem Akademi Yayınları.

Deutsch, K. (1966). Nationalism and social communication: An inquiry into the foundatioans of nationality. Mass: MIT Oress, Cambridge.

Emerson, R. (1965). Sömürgelerin uluslaşmast: Asya Afrika halklartnın ortaya çıkması. (Çev. Tükkaya Ataöv). Ankara: Türk Siyasi İlimler Derneği Yayınları.

Gellner, E. (1983). Nations and nationalism. Oxford: Blacwell.

Giddens, A. (2005). Ulus devlet ve şiddet (1985). (Çev. Cumhur Atay). İstanbul: Devin Yayıncılık.

Gökalp, Z. (1976). Türkçülüğün esasları, 1.Bask1. İstanbul: Kültür Bakanlığı Yayınları.

Guehenno, J. M. (1998). Demokrasinin sonu. (Çev. Mehmet Emin Özcan). Ankara: Dost Yayınları Kitabevi.

Guibernau, M. (1996). Milliyetçiliğin politik niteliği. milliyetçilik ve ulus devlet. İktisat Dergisi, Aralık.

Guibernau, M. (1997). 20. yüzyılda ulus devlet ve milliyetçilikler. (Çev. Neşe Nur Domaniç). İstanbul: Sarmal Yayınevi.

Habermas, J. (2002). Küreselleşme ve milli devletlerin akıbeti. İstanbul: Bakış Yayınları.

Held, D. (2001). The development of modern state. In Hall S. And Gieben, B. (Eds.). Formations of modernity (pp. 71-126). Polity Press in Association with the Open University.

Hobsbawn, E. J. (1995). 1780'den günümüze milletler ve milliyetçilik- 
ler: Program, mit, Gerçeklik. (Çev. Osman Akınhay). İstanbul: Ayrıntı Yayınları.

İçduygu, A. ve Keyman, E. F. (2004). Globalleşme anayasallık ve Türkiye'de vatandaşlık tartışması. Doğu Batı, sayı 5, 157-170.

Jeong, J. (2004). Analysis of the factors and the roles of hrd in organizational learning styles as identified by key informants at selected corporations in the Republic of Korea. Unpublished Doctoral Thesis, Texas A\&M University, USA.

Kaya, A. (2000). Yurttaşlık, azınlıklar ve çokkültürlülük. T.H. Marshall ve T. Bottomore (Ed.) Yurttaşlık ve toplumsal sinıflar. (Çev. Ayhan Kaya) (ss. 135-171). Ankara: Gündoğan Yayınları.

Kline, P. (1994). An easy guide to factor analysis. London: Routledge.

Köktürk, M. (2004). Kıskaçtaki ulus devlet. Türk Yurdu, 24 (207), Ankara.

Leca, J. (1998). Neden söz ediyoruz?. Jean Leca (Haz.) Uluslar ve milliyetçilikler (ss. 11-19). İstanbul: Metis Yayınları.

Mann, M. (2001). Explaining murderous ethnic cleansing: The macro level. In Monserrat Guibernau and John Hutchinson (Eds.) Understanding nationalism (pp. 75-98). Cambridge: Polity Press.

Mauss, M. (2005). Sosyoloji ve antropoloji: Doğu Batı Yayınları.

Navari, C. (1981). The origins of the nation-state. In Leonard Tivey (Eds.). The nation state: The formation of modern politics ( $\mathrm{pp}$. 30-52). New York: ST. Martin's Press Inc.

Özkırımlı, U. (1999). Milliyetçilik kuramları. İstanbul: Sarmal Yayınevi.

Özdamar, K. (1997). Paket programlar ile istatistiksel veri analizi I. Eskişehir: Anadolu Üniversitesi Fen Fakültesi Yayınları.

Raanan, Uri (1991). The nation-state fallacy In Montville Joseph V. (Ed.). Conflict and peacemaking in multiethnic societies. New York: Lexington Books.

Smith, A. D. (2002). Küreselleşme çağında milliyetçilik. (Çev. Derya Kömürcü). İstanbul: Everest Yayınları.

Smith, A. D. (2002). Milli kimlik. (Çev. Bahadır Şener). İstanbul: İletişim Yayınları.

Stalin, J. (1976). Marksizm, ulusal sorun ve sömürge sorunu. (Çev. 
Muzaffer Ardos). Sol Yayınlar1.

Şencan, H. (2005). Sosyal ve davranışsal ölçümlerde güvenirlik ve geçerlik. Ankara: Seçkin Yayınları.

Tabachnick, B. G. \& Fidel, L. S. (2001). Using multivariate statistics, Fourth Edition. Needham Heights, MA: Allyn \& Bacon.

Tiily, C. (2001). Zor, Sermaye ve Avrupa Devletlerinin oluşumu. (Çev. Kudret Emiroğlu). İstanbul: İmge Kitabevi.

Tok, N. (2003). Kültür, kimlik ve siyaset. İstanbul: Ayrıntı Yayınları.

Weber, M. (1993). Sosyoloji yazıları. (Çev. Taha Parla). İstanbul: Hürriyet Vakfı Yayınları. 